\title{
Comparative efficacy of ascorbic acid, adrenaline and oxytetracycline supplementation against nitrite poisoning in rats (Rattus norvegicus)
}

\author{
F. Yasmin ${ }^{5}$, M. A. Awal, A. Ghosh ${ }^{*}$, M. B. Rashed and M. Mostofa \\ Department of Pharmacology, Faculty of Veterinary Science, Bangladesh Agricultural \\ University, Mymensingh-2202, Bangladesh
}

\begin{abstract}
The effects of methylene blue, vitamin $C$, adrenaline and oxytetracycline against sodium nitrite intoxication was studied in Long Evan's (Rattus norvegicus) rats $(n=128)$ in eight groups $(\mathrm{A}-\mathrm{H})$. Except control, intoxication was produced by administering sodium nitrite. Rats were treated with methylene blue (group C), vitamin C (group D), adrenaline (group E) and oxytetracycline (group F), and with vitamin $\mathrm{C}$, adrenaline and oxytetracycline (group G); methylene blue, vitamin $\mathrm{C}$, adrenaline and oxytetracycline (Group H). Rats of group C and group H recovered within 24-72 and 13-40 hours, respectively. Other groups showed severe toxic signs including excitement, restlessness, muscle tremor, anoxia, and coma, followed by death within 60 hours. Total erythrocyte count, total leukocyte count, haemoglobin content and packed cell volume were significantly $(\mathrm{p}<0.01)$ reduced, and returned to normal at day 14 after methylene blue treatment. The activities of alanine aminotransferase (ALT) and aspartate aminotransferase (AST) were elevated significantly $(\mathrm{p}<0.01)$ in all intoxicated groups and within 14 days ALT values reached normal level after methylene blue administration. (Bangl. vet. 2007. Vol. 25, No. 1, 25-31)
\end{abstract}

\section{Introduction}

Plants absorb nitrogen from the soil in the form of nitrates. Normally, plants contain relatively small amounts of nitrate. However, during droughts the amount of nitrate in the soil may greatly increase because of lack of leaching, decomposition of organic matter and reduced uptake by plants. After the drought, nitrate uptake by plants may be high. Nitrite may be absorbed directly from decomposed or mouldy fodder.

Factors influencing nitrate/nitrite poisoning are intake of large amounts of poisonous plants, weakness, hypervitaminosis A, poor quality of carbohydrate in diet, poor feeding practice, hepatic disease, deficiency of copper, molybdenum, iron (Ye-HaiMei et al., 2006).

\footnotetext{
${ }^{5}$ Livestock Research Institute, Department of Livestock Services, Mohakhali, Dhaka, Bangladesh

6 Upazila Livestock Officer, Department of Livestock Services, PhD Fellow, Department of Pharmacology, Bangladesh Agricultural University, Mymensingh, Bangladesh

*Correspondence :- E-mail : amalend_ghosh@yahoo.com
} 
Nitrate in the rumen is normally broken down by microbial action to nitrite and then to ammonia. Following absorption of nitrite, haemoglobin is converted to methaemoglobin, which reduces the ability of the blood to transport oxygen. If the nitrite level is high enough, death can occur through oxygen starvation. It is suggested that $1 \mathrm{~g}$ sodium nitrite could convert as much as $1855 \mathrm{~g}$ haemoglobin to methaemoglobin (Lehman, 1958). The formation of methaemoglobin can be antagonized by methylene blue and this effect is enhanced by oxygen (Sheehy and Way, 1974).

In Bangladesh, causes of nitrate/nitrite poisoning and losses imposed by it remained unclear (Sobhan, 1980). Chief source of nitrate poisoning is the accidental ingestion of plants and grasses containing nitrate (Canzi, 2002).

Information about toxicity and therapy in Bangladesh is scanty. The present study was undertaken to find out the effects of methylene blue, vitamin $\mathrm{C}$, adrenaline and oxytetracycline alone and in combination against nitrite intoxication in rats.

\section{Materials and Methods}

Animal selection and care

One hundred and twenty eight (60-day-old) Long Evan's rat (Rattus norvegicus) weighing 200-300g were collected from International Centre for Diarrhea Disease Research, Bangladesh (ICDDR'B), Dhaka. Animals were kept for 2 weeks in the laboratory under close observation prior to studies. All rats were maintained with ambient temperature $22 \pm 2{ }^{\circ} \mathrm{C}$, humidity $60 \pm 5 \%$ in a photoperiod-controlled room (14h light: 10h dark) with free access to standard laboratory food (20 gm/rat/day) and water ad libitum. The experimental protocol was approved by the Animal Ethics Committee of the department.

\section{Grouping and treatments}

Rats were randomly divided into eight groups each comprising 16 rats A - H. All groups were housed separately in a compartmented rectangular metallic cage. All feedings were administered separately as a single oral dose diluted in distilled water. Control group (A) received $1 \mathrm{ml}$ of distilled water and all other groups received sodium nitrite (E. Merck, Germany) @ $75 \mathrm{mg} / \mathrm{kg}$ orally. In addition to sodium nitrite group $\mathrm{C}-\mathrm{H}$ were treated as follows. Group $\mathrm{C}$ received intra-peritoneal methylene blue (Loba-Chemie Ltd, India) @ $15 \mathrm{mg} / \mathrm{kg}$, group D received vitamin C (Tab Ceevit $^{\circledR}$, Square Pharmaceutical Bangladesh Ltd.) @ $10 \mathrm{mg} / \mathrm{kg}$ orally, group E adrenaline (Inj Adrenaline, Gaco Pharmaceutical Bangladesh Ltd.) @ $0.5 \mathrm{ml} / \mathrm{rat}$ subcutaneously and group $\mathrm{F}$ received oxytetracycline (Renamycin $\mathrm{Tab}^{\circledR}$, Renata Animal Health, Bangladesh Ltd.) @ $25 \mathrm{mg} / \mathrm{kg}$ orally. Group G received vitamin C, adrenaline and oxytetracycline at previous doses and group $\mathrm{H}$ methylene blue, vitamin $\mathrm{C}$, adrenaline and oxytetracycline at previous doses. All the rats were kept under close observation for 14 days. 


\section{Animal sacrifice and blood collection}

For studying haematological and biochemical parameters four rats of each group was sacrificed just after treatment and at 12 hours, three days and 14 days under light ether anaesthesia. About $5 \mathrm{ml}$ blood was collected from each animal by cardiac puncture using disposable syringe with 23G needles. Aliquot of blood was transferred to sterile tubes containing heparin for haematology. Serum was separated from remaining part and stored at $-20^{\circ} \mathrm{C}$ until biochemical analysis.

\section{Common pathological changes}

Immediately after euthanasia or just after death, the carcasses were examined systematically. Gross pathological changes were noted.

\section{Haematological parameters}

Total erythrocyte count (TEC), total leukocyte count (TLC), haemoglobin content $(\mathrm{Hb})$ and Packed cell volume (PCV) were determined by standard method (Coffin, 1955).

\section{Biochemical parameters}

Serum alanine aminotransferase (ALT) and aspartate aminotransferase (AST) were measured by standard procedure (Deneke et al., 1985) using Reflotron ${ }^{\circledR}$ (Boehringer mannheim, Germany). All the biochemical tests were performed at $37^{\circ} \mathrm{C}$.

\section{Statistical analyses}

Data were analysed using student's T-test (paired) as described by Zar (2003) and are presented as mean \pm S.E.

\section{Results and Discussion}

\section{Poisonous signs}

Rats of control group (A) remained normal, but nitrite.intoxicated group (B) died within 35-50 min of feeding showing excitement, muscle tremor, restlessness, salivation, anoxia, gasping and coma. But the rats given methylene blue (group C) and methylene blue plus vitamin $\mathrm{C}$, adrenaline and oxytetracycline (group $\mathrm{H}$ ) became fully cured within 24-72 and 13-40 hours, respectively, after showing mild excitement, restlessness, salivation and incoordination. Rats of all other groups died within 24-60 hours of treatment showing signs of nitrate intoxication.

Administration of methylene blue alone and in combination with vitamin C, adrenaline and oxytetracycline were $100 \%$ effective against nitrite poisoning in rats. However, recovery was slightly faster following combined treatment. On the other hand, the administration of treatment with vitamin $\mathrm{C}$, adrenaline or oxytetracycline alone was ineffective, although administration of vitamin $\mathrm{C}$ and adrenaline prolonged survival from 50 minutes to 12 hours but did not save the animals (Appenroth and Winnefeld, 1998). It has been reported that ascorbic acid and vitamin 
E ( $\alpha$-tocopherol) were not promising as treatments for acute poisoning (Bradberry, 2003). Use of oxytetracycline might stop microbial production of nitrite, which helps reduce poisoning. Further, as vasoconstrictors, adrenalin can save lives in acute cases (Cawley et al., 1977; Malone, 1978). The present findings confirm the efficacy of methylene blue against nitrite poisoning, as reported by many authors (Katsoulos et al, 2004; Zhao et al., 1992).

\section{Common pathological changes}

All the organs were normal in control group (A). In group $\mathrm{H}$, treated with methylene blue plus vitamin $\mathrm{C}$, adrenaline and oxytetracycline, all organs appeared normal. Slight congestion with minute haemorrhages in the liver, lung, intestine, stomach and kidney were found in rats treated with methylene blue (group C). On the other hand, all other groups had highly haemorrhagic stomach and intestine with brownish discoloration of the blood suggesting methaemoglobinaemia. These findings accord with previous work (Antoine et al., 1993; Zhao et al., 1992).

\section{Effects on haematological factors}

The effects of sodium nitrite alone and treated with methylene blue, vitamin $\mathrm{C}$ and adrenaline supplementation on TEC, TLC, $\mathrm{Hb}$ and PCV are presented in Tables 1 and 2. In the group treated with methylene blue $(C)$ significant $(p<0.01)$ reduction of TEC, TLC, $\mathrm{Hb}$ and PCV were recorded at 12 hours of intoxication and at day 3 it started to increase but returned to normal at day 14 . Similar result was found in the group treated with methylene blue plus vitamin $C$, adrenaline and oxytetracycline $(H)$. But in other groups $(D, E, F \& G)$, the values were reduced significantly $(p<0.01)$ till death. All the rats of group B showed significantly reduced haematological values compared to control after intoxication. Recently, administration of methylene blue against nitrate poisoning at $20 \mathrm{mg} \mathrm{kg}^{-1}$ in cattle decreased methaemoglobinaemia and restored haematological values (Issi et al., 2008), which accords with this study. The present findings confirm earlier work (Bhikane and Bhoop, 1991; Emerson et al, 1999). The reduction of haematological parameters might be due to toxic effects on the haematopoietic organs and haemolysis of the erythrocytes.

\section{Biochemical factors}

The biochemical values are presented in Table 3. In control group, AST and ALT values were normal throughout the experimental period. AST and ALT were elevated in all groups after intoxication. In the group treated with methylene blue (C) and with methylene blue plus vitamin $C$, adrenaline and oxytetracycline $(\mathrm{H})$ significant $(p<0.01)$ elevation was found at 12 hours and after that the values started to decline. At day 14 the ALT values reached normal, AST value was diminished but remained slightly higher than the control in the same period. AST and ALT were significantly $(\mathrm{p}<0.01)$ elevated in groups $\mathrm{D}, \mathrm{E}, \mathrm{F}$ and $\mathrm{G}$ till death. 
Table 1. Effects of sodium nitrite alone and in combination with methylene blue, vitamin C, adrenaline and oxytetracycline on TEC and TLC in rats

\begin{tabular}{|c|c|c|c|c|c|}
\hline \multirow[t]{2}{*}{ Parameters } & \multirow[t]{2}{*}{ Treatments } & \multicolumn{4}{|c|}{ Time after intoxication } \\
\hline & & 0 minute & $12^{\text {th }}$ hour & $3^{\text {rd day }}$ & $14^{\text {th }}$ day \\
\hline TEC & Control & $8.9 \pm 0.1$ & $9.0 \pm 0.1$ & $8.7 \pm 0.1$ & $8.7 \pm 0.1$ \\
\hline \multirow[t]{7}{*}{$\left(X 10^{6} / \mathrm{dl}\right)$} & $\mathrm{NaNO}_{2}$ & $8.0 \pm 0.2$ & - & - & - \\
\hline & $\mathrm{NaNO}_{2}+$ Methylene blue & $8.1 \pm 0.2$ & $6.9 \pm 0.2^{b}$ & $7.7 \pm 0.2$ & $8.1 \pm 0.3$ \\
\hline & $\mathrm{NaNO}_{2}+\mathrm{VitC}$ & $8.3 \pm 0.1$ & $6.9 \pm 0.2^{b}$ & - & - \\
\hline & $\mathrm{NaNO}_{2}+$ Adrenaline & $7.9 \pm 0.2$ & $6.4 \pm 0.3^{b}$ & - & - \\
\hline & $\mathrm{NaNO}_{2}+$ Oxytetracycline & $8.6 \pm 0.1$ & $7.0 \pm 0.2 \mathrm{~b}$ & _ & - \\
\hline & $\begin{array}{l}\mathrm{NaNO}_{2}+\text { Vit } \mathrm{C}+\text { Adrenaline } \\
+ \text { Oxytetracycline }\end{array}$ & $8.1 \pm 0.2$ & $7.8 \pm 0.2^{b}$ & - & - \\
\hline & $\begin{array}{l}\mathrm{NaNO}_{2}+\text { Methylene blue }+ \text { Vit C } \\
+ \text { Adrenaline + Oxytetracycline }\end{array}$ & $8.4 \pm 0.2$ & $7.7 \pm 0.2^{b}$ & $7.4 \pm 0.3$ & $8.3 \pm 0.2^{a}$ \\
\hline TLC & Control & $9.6 \pm 0.1$ & $9.5 \pm 0.1$ & $9.9 \pm 0.2$ & $9.3 \pm 0.2$ \\
\hline \multirow[t]{7}{*}{$\left(\mathrm{X} 10^{3} / \mathrm{dl}\right)$} & $\mathrm{NaNO}_{2}$ & $8.9 \pm 0.2$ & - & - & - \\
\hline & $\mathrm{NaNO}_{2}+$ Methylene blue & $9.9 \pm 0.3$ & $8.4 \pm 0.2^{b}$ & $9.1 \pm 0.2$ & $9.5 \pm 0.2^{a}$ \\
\hline & $\mathrm{NaNO}_{2}+$ Vit-C & $8.4 \pm 0.2$ & $8.1 \pm 0.1^{b}$ & - & - \\
\hline & $\mathrm{NaNO}_{2}+$ Adrenaline & $9.4 \pm 0.1$ & $8.4 \pm 0.2 \mathrm{~b}$ & - & - \\
\hline & $\mathrm{NaNO}_{2}+$ Oxytetracycline & $10.0 \pm 0.1$ & $9.1 \pm 0.2^{b}$ & - & - \\
\hline & $\begin{array}{l}\mathrm{NaNO}_{2}+\text { Vit-C + Adrenaline } \\
+ \text { Oxytetracycline }\end{array}$ & $9.5 \pm 0.1$ & $8.8 \pm 0.2^{b}$ & - & - \\
\hline & $\begin{array}{l}\mathrm{NaNO}_{2}+\text { Methylene blue }+ \text { VitC } \\
+ \text { Adrenaline + Oxytetracycline }\end{array}$ & $10.3 \pm 0.1$ & $9.0 \pm 0.2^{b}$ & $9.1 \pm 0.2$ & $10.1 \pm 0.3^{\mathrm{a}}$ \\
\hline
\end{tabular}

Values represent mean $\pm S E$; a significantly increased $(\mathrm{p}<0.01) ;{ }^{b}$ significantly decreased $(\mathrm{p}<0.01)$

Table 2. Effects of sodium nitrite alone and in combination with methylene blue, vitamin $\mathrm{C}$, adrenaline and oxytetracycline supplementation on $\mathrm{Hb}$ and PCV in rats

\begin{tabular}{|c|c|c|c|c|c|}
\hline \multirow[t]{2}{*}{ Parameters } & \multirow[t]{2}{*}{ Treatments } & \multicolumn{4}{|c|}{ Time after intoxication } \\
\hline & & 0 minute & $12^{\text {th }}$ hour & $3^{\text {rd }}$ day & $14^{\text {th }}$ day \\
\hline \multirow[t]{8}{*}{$\mathrm{Hb}(\mathrm{gm} / \mathrm{dl})$} & Control & $13.5 \pm 0.1$ & $13.4 \pm 0.0$ & $13.3 \pm 0.1$ & $13.4 \pm 0.0$ \\
\hline & $\mathrm{NaNO}_{2}$ & $13.2 \pm 0.1$ & - & - & - \\
\hline & $\mathrm{NaNO}_{2}+$ Methylene blue & $13.6 \pm 0.1$ & $10.4 \pm 0.2^{b}$ & $11.40 \pm 0.3$ & $12.5 \pm 1.3^{\mathrm{a}}$ \\
\hline & $\mathrm{NaNO}_{2}+\mathrm{VitC}$ & $13.2 \pm 0.2$ & $9.6 \pm 0.2 b$ & - & - \\
\hline & $\mathrm{NaNO}_{2}+$ Adrenaline & $13.8 \pm 0.1$ & $9.8 \pm 0.2^{b}$ & - & - \\
\hline & $\mathrm{NaNO}_{2}+$ Oxytetracycline & $13.6 \pm 0.1$ & $10.2 \pm 0.3^{b}$ & - & - \\
\hline & $\begin{array}{l}\mathrm{NaNO}_{2}+\text { Vit- } \mathrm{C}+\text { Adrenaline } \\
+ \text { Oxytetracycline }\end{array}$ & $13.4 \pm 0.1$ & $11.2 \pm 0.2^{\mathrm{b}}$ & - & - \\
\hline & $\begin{array}{l}\mathrm{NaNO}_{2}+\text { Methylene blue }+ \text { Vit } \mathrm{C} \\
\text { + Adrenaline + Oxytetracycline }\end{array}$ & $13.8 \pm 0.2$ & $10.4 \pm 0.3^{b}$ & $11.8 \pm 0.4$ & $12.3 \pm 0.3^{\mathrm{a}}$ \\
\hline \multirow[t]{8}{*}{$\mathrm{PCV}(\%)$} & Control & $46.0 \pm 0.1$ & $46.6 \pm 0.1$ & $46.1 \pm 0.1$ & $46.0 \pm 0.2$ \\
\hline & $\mathrm{NaNO}_{2}$ & $46.1 \pm 0.2$ & - & - & - \\
\hline & $\mathrm{NaNO}_{2}+$ Methylene blue & $45.9 \pm 0.1$ & $35.1 \pm 0.2^{b}$ & $38.22 \pm 0.2$ & $45.1 \pm 0.2^{\mathrm{a}}$ \\
\hline & $\mathrm{NaNO}_{2}+$ Vit C & $45.8 \pm 0.2$ & $32.0 \pm 0.2^{b}$ & - & - \\
\hline & $\mathrm{NaNO}_{2}+$ Adrenaline & $46.1 \pm 0.2$ & $34.1 \pm 0.3 \mathrm{~b}$ & - & - \\
\hline & $\mathrm{NaNO}_{2}+$ Oxytetracycline & $46.0 \pm 0.1$ & $35.5 \pm 0.2^{b}$ & & \\
\hline & $\begin{array}{l}\mathrm{NaNO}_{2}+\text { Vit } \mathrm{C}+\text { Adrenaline } \\
+ \text { Oxytetracycline }\end{array}$ & $46.1 \pm 0.1$ & $36.6 \pm 0.2^{b}$ & & \\
\hline & $\begin{array}{l}\mathrm{NaNO}_{2}+\text { Methylene blue }+ \text { Vit C } \\
+ \text { Adrenaline + Oxytetracycline }\end{array}$ & $46.2 \pm 0.1$ & $36.5 \pm 0.4^{b}$ & $41.5 \pm 0.4$ & $45.3 \pm 0.3^{a}$ \\
\hline
\end{tabular}

Values represent mean $\pm S E$; a significantly increased $(p<0.01) ;{ }^{b}$ significantly decreased $(p<0.01)$ 
Table 3. Effects of sodium nitrite alone and in combination with methylene blue, vitamin $\mathrm{C}$, adrenaline and oxytetracycline supplementation on AST (U/L) and ALT $(\mathrm{U} / \mathrm{L})$ in rats

\begin{tabular}{|c|c|c|c|c|c|}
\hline \multirow[t]{2}{*}{ Parameters } & \multirow[t]{2}{*}{ Treatments } & \multicolumn{4}{|c|}{ Time after intoxication } \\
\hline & & 0 minute & 12 hour & $3^{\text {rd }}$ day & $14^{\text {th }}$ day \\
\hline \multirow{8}{*}{ AST (U/L) } & Control & $51.6 \pm 0.1$ & $51.6 \pm 0.1$ & $51.6 \pm 0.1$ & $51.6 \pm 0.1$ \\
\hline & $\mathrm{NaNO}_{2}$ & $132.3 \pm 0.7$ & - & - & - \\
\hline & $\mathrm{NaNO}_{2}+$ Methylene blue & $180.5 \pm 0.6$ & $269.4 \pm 0.8 \mathrm{a}$ & $148.3 \pm 0.8$ & $92.4 \pm 0.7 \mathrm{~b}$ \\
\hline & $\mathrm{NaNO}_{2}+$ Vit-C & $148.6 \pm 0.5$ & $138.6 \pm 0.4^{a}$ & - & - \\
\hline & $\mathrm{NaNO}_{2}+$ Adrenaline & $159.2 \pm 0.6$ & $127.6 \pm 0.4^{\mathrm{a}}$ & - & - \\
\hline & $\mathrm{NaNO}_{2}+$ Oxytetracycline & $189.6 \pm 0.7$ & $125.6 \pm 0.3^{a}$ & - & - \\
\hline & $\begin{array}{l}\mathrm{NaNO}_{2}+\text { Vit } \mathrm{C}+\text { Adrenaline }+ \\
\text { Oxytetracycline }\end{array}$ & $151.3 \pm 0.7$ & $125.6 \pm 0.4^{a}$ & - & - \\
\hline & $\begin{array}{l}\mathrm{NaNO}_{2}+\text { Methylene blue + Vit C } \\
+ \text { Adrenaline + Oxytetracycline }\end{array}$ & $176.6 \pm 0.7$ & $256.4 \pm 0.8^{a}$ & $178.2 \pm 0.7$ & $99.4 \pm 0.6^{b}$ \\
\hline \multirow[t]{8}{*}{ ALT (U/L) } & Control & $47.2 \pm 0.2$ & $46.8 \pm 0.3$ & $49.6 \pm 0.1$ & $48.7 \pm 0.1$ \\
\hline & $\mathrm{NaNO}_{2}$ & $68.8 \pm 0.7$ & - & - & - \\
\hline & $\mathrm{NaNO}_{2}+$ Methylene blue & $76.4 \pm 0.6$ & $72.3 \pm 0.7 \mathrm{a}$ & $64.4 \pm 0.7$ & $51.6 \pm 0.5^{b}$ \\
\hline & $\mathrm{NaNO}_{2}+$ Vit-C & $73.2 \pm 0.6$ & $82.3 \pm 0.6^{\mathrm{a}}$ & - & - \\
\hline & $\mathrm{NaNO}_{2}+$ Adrenaline & $68.5 \pm 0.4$ & $77.3 \pm 0.9 \mathrm{a}$ & - & - \\
\hline & $\mathrm{NaNO}_{2}+$ Oxytetracycline & $72.2 \pm 0.4$ & $82.3 \pm 0.6^{\mathrm{a}}$ & - & - \\
\hline & $\begin{array}{l}\mathrm{NaNO}_{2}+\text { Vit } \mathrm{C}+\text { Adrenaline } \\
\text { + Oxytetracycline }\end{array}$ & $66.3 \pm 0.5$ & $76.3 \pm 0.6^{a}$ & - & - \\
\hline & $\begin{array}{l}\mathrm{NaNO}_{2}+\text { Methylene blue }+ \text { Vit C } \\
+ \text { Adrenaline + Oxytetracycline }\end{array}$ & $79.3 \pm 0.8$ & $76.6 \pm 0.6^{a}$ & $69.3 \pm 0.6$ & $52.2 \pm 0.3 b$ \\
\hline
\end{tabular}

Values represent mean $\pm S E$; a significantly increased $(p<0.01) ;{ }^{b}$ significantly decreased $(p<0.01)$

ALT is increased in acute viral or toxic hepatitis, jaundice, and liver cirrhosis, and AST is increased in myocardial infarction, and liver cancer and cirrhosis. The elevation of AST and ALT suggests abnormal liver function. Restoration of biochemical values were observed after treatment with methylene blue as an antidote in cattle (Issi et al., 2008). Similar result was observed by others (Bhikane and Bhoop, 1990; Tyburczyk et al., 1991).

Nitrite/nitrate poisoning can be treated effectively by methylene blue. It restores haemoglobin to its normal state, allowing oxygenation of the blood. However, administration of vitamin $C$, adrenaline and oxytetracycline in addition to methylene blue is more effective in nitrate poisoning.

\section{References}

Antoine D, Thejomoorthy P, Napolean RE, Prabakar TG, Rao VNA 1993: Nitrite poisoning in cattle. Indian Veterinary Journal 70 1172-1173.

Appenroth D, Winnefeld K 1998: Vitamin E and C in the prevention of metal nephrotoxicity in developing rats. Experimental and Toxicologic Pathology 50 391-396.

Bhikane AU, Bhoop S 1990: Therapeutic efficacy of methylene blue against experimental nitrite poisoning in crossbred calves. Indian Veterinary Journal 67 459-462. 
Bhikane AU, Bhoop S 1991: Clinico-pathological changes in experimental nitrite poisoning in cross bred calves. Indian Journal of Animal Health 30 123-126.

Bradberry SM 2003: Occupational methemoglobinemia: mechanisms of production, features, diagnosis and management including the use of methylene blue. Toxicological Review 22 13-27.

Canzi F 2002: Nitrates and nitrites in feed destined for dairy cattle: guidelines, health risks and prevention. Large-Animals-Review 8 15-21.

Cawley GD, Collings DF, Dyson DA 1977: Nitrate poisoning. Veterinary Record 101 305-306.

Coffin DL 1955: Manual of Veterinary Clinical Pathology. $3^{\text {rd }}$ edn. Coinstock Publishing Associates Inc. Ithaca, New York. pp. 116-157.

Deneke U, Rittersdorf W, Werner W 1985: Performance data of Reflotron-GOT (AST) dry chemistry test for Reflotron. Clinical Chemistry 31 921-926.

Emerson M, Momi S, Paul W, Alberti PF, Page C, Gresele P 1999: Endogenous nitric oxide acts as a natural antithrombotic agent in vivo by inhibiting platelet aggregation in the pulmonary vasculature. Thromb Haemost 81 961-966.

Issi M, Gul Y, Atessahin A, Karahan I 2008: Acute nitrate poisoning in two cattle. Toxicological \& Environmental Chemistry 90135 - 140.

Katsoulos PD, Panousis N, Karatzias H 2004: Nitrite poisoning in ruminants. Journal of the Hellenic Veterinary Medical Society 55 226-234.

Lehman AJ 1958: Absorption, distribution and biochemical reactions of nitrite poisoning. Quart Bulletin Association Food Drug 22136.

Malone P 1978: Monensin sodium toxicity in cattle. Veterinary Record 103 477-478.

Sheehy MW, Way JL 1974: Nitrite intoxication: Protection with methylene blue and oxygen. Toxicological Applied Pharmacology 30 221-225.

Sobhan MA 1980: Nitrate/nitrite poisoning of cattle in Bangladesh. Niramoy 2 8-9 and 2021.

Tyburczyk W, Borkowska J, Klimek K 1991: Examination of dynamic changes of certain biochemical parameters in blood of rats poisoned with sodium nitrite. Rocz Panstw Zakl Hig 42 423-429.

Ye-HaiMei, Chen-GuiXiang, Zhou-JingSong 2006: Survey of a food poisoning accident due to nitrite. China Tropical Medicine 6 2096-2097.

Zar, JH 2003: Biostatistical Analysis. $4^{\text {th }}$ edn. Pearson Education (Singapore) Ptv Ltd, Singapore, pp. 161-176.

Zhao DM, Di BX, Gao QY, YURP 1992: Observation on nitrite poisoning in ducks. Chinese Journal of Veterinary Medicine 18 33-36. 